\section{RECORD OF MOR'TALITY}

For the WheK ending Saturday, Novemiere 12, 1892.

\begin{tabular}{|c|c|c|c|c|c|c|c|c|c|}
\hline \multirow{2}{*}{\multicolumn{2}{|c|}{ Citles. }} & \multirow{2}{*}{ 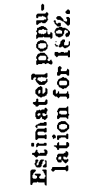 } & \multirow[b]{2}{*}{ 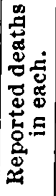 } & \multirow[b]{2}{*}{ 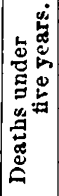 } & \multicolumn{5}{|c|}{ Percentage of denths from } \\
\hline & & & & & 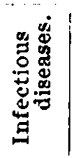 & 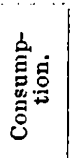 & 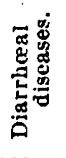 & 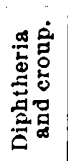 & 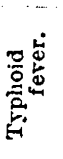 \\
\hline ork & & $1, k 27,396$ & $(220)$ & 200 & 13.24 & 17.28 & 2.40 & $(i, 88$ & $1.7 \mathrm{i}$ \\
\hline & & $1,25,0,(1,4)$ & 4lii & $17: 3$ & $19.6 \%$ & 1:5.34; & $1.15 k$ & 12.24 & $2.14 i$ \\
\hline iladelphia & . & $1,(09) 2,168$ & 401 & $12: 2$ & 18.77 & 12.84 & 2.47 & 12.35 & .74 \\
\hline rooklyn & . & 955,33333 & 301 & 93 & 11.88 & 23.76 & 1.00 & 7.20 & 1.32 \\
\hline Louis. & . & $4 \pi \pi, \times 73$ & -1 & - & $\pi$ & $\overline{14}$ &,$\overline{04}$ & $\overline{10}$ & 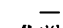 \\
\hline ston . & - & $4(6 ;), 6+15$ & 245 & it & 17.95 & 14.28 & 2.04 & 8.16 & 3.26 \\
\hline IBalt & - & $461,13:)$ & - & - & -1 & - & $\overline{3}$ & $\overline{z^{\prime \prime}}$ & $\overline{11}$ \\
\hline ttI & . & 305,1000 & $k !$ & 31 & $13 .+4$ & 14.56 & $3.36 i$ & 6.72 & 1.12 \\
\hline uld & & $2 \times 1,353$ & 10! & 46 & $17.3 x$ & ...6ix & 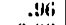 & 13.4 .4 & 1.92 \\
\hline$r g$ & • & $255,(1000$ & (9) & 41 & 32.32 & 12.12 & 6.06 & 12.12 & 505 \\
\hline 30 . & . & 234,440 & 55 & $2 !$ & 30.94 & 3. 1.50 & - & 25.16 & D.4ti \\
\hline bon & . & $230,3(30)$ & $81 ;$ & 27 & 11.61 & 15.tix & 1.16 & 6.96 & $3.1 x$ \\
\hline 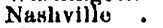 & & 87,754 & 20 & 4 & 5.061) & $10 .(10)$ & - & - & 5.00 \\
\hline 11 & & 56,048 & 34 & 11 & $6.8 \mathrm{x}$ & 2.94 & 5.88 & - & - \\
\hline d. & & $4(1,000$ & 7 & 1 & - & 28.56 & - & - & - \\
\hline stor & & 92,313 & 25 & i & 75.00 & 2.5 .00 & 50.00 & 25.00 & - \\
\hline & & 82,466 & 31 & y) & 3.23 & 12.92 & - & - & 3.23 \\
\hline vor & & $x^{2}, 128$ & 22 & 8 & 36.10 & 4.55 & 13.65 & 9.10 & 4.65 \\
\hline riligo & & 74,644 & 14 & (j) & 7.14 & $2 \times .5 i$ & - & - & - \\
\hline & & $(i 0,8(0)$ & 13 & 5 & 15.38 & 7.69 & - & - & 7.69 \\
\hline ld & & 47.052 & $\mathbf{y}$ & 2 & 44.44 & - & - & - & 22.22 \\
\hline 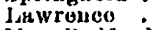 & & 45,810 & 22 & 7 & 22.75 & 18.20 & - & 9.10 & 9 10 \\
\hline Iford & & 44,947 & 20 & 7 & - & $5.90)$ & - & - & - \\
\hline 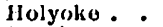 & & & -1 & - & - & - & - & -1 & - \\
\hline on & & $32,7 \times 3$ & 8 & 0) & - & 12.50 & - & -1 & - \\
\hline .. & & 31,495 & 7 & 2 & 42.84 & 14.28 & 28.56 & - & 14.28 \\
\hline rhill & & 30, & c & 2 & 33.33 & & 16.600 & - & 1606 \\
\hline NeA. & & 29.4 & 8 & 4 & - & 12.50 & - & - & - \\
\hline Malden . & & & 4 & C & 23.00 & - & - & - & $25.06)$ \\
\hline Newton . & & $2(6,4 ! 15)$ & - & - & - & - & - & - & - \\
\hline ton. & & & 12 & 4 & 8.33 & - & - & - & - \\
\hline ter & & & 3 & 1 & 33.333 & - & - & - & - \\
\hline urg & & 1 & (6) & 1 & - & & - & -1 & - \\
\hline Waithan & & 20,942 & 14 & 1 & 7.14 & 35.70 & - & -1 & - \\
\hline Quine & & $1 \times, 6(69)$ & b) & 3 & 20.00 & - & - & - & - \\
\hline [old & & $1 \times, 29.4$ & 3 & 3 & - & - & - & - & - \\
\hline mampton & & $15,1 \times 4$ & 1 & 0 & - & & 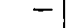 & & - \\
\hline & & & $x$ & 3 & - & $37 . \tilde{0} 0$ & - & 一 & - \\
\hline gort & & 14, & 2 & 0) & - & - & - & - & - \\
\hline mesbury . & & 33,561 & 2 & () & - & - & - & - & - \\
\hline
\end{tabular}

Deaths reported 2,746 : under five years of age $962 ;$ principal infectious diseases (small-pox, moasles, diphtlieria and croup, diarrhosul diseases, whooping.cough, erysipelas and fevers) 462 acute lung diseases $4: 22$, consumption 302 , diplstlieria and eroul 251 , dinrricoal diseases i4, typhoid fever 58 , searlot fever 37 . whooping-cough 14, measles 13, cerobro-spinal meningitis 9, malarial fever 8 , erysipelats 5 , smatl-pox 1 .

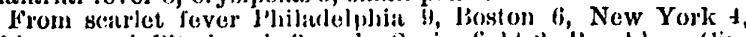
Chicago and Pittshngh 3 each, Springfield 2, Brooklyn, Cincinnati, Cleveland, Fall Kiver, Cambridge, Law rence, 'Aatumon, Gloucester, Walthan and Adams 1 each. From whouping cough New York 6, Chicago 4, Philadelphiat 2, boston and Cincinnati 1 each. From measles Chichgo 6, Now York 4, Boston 2, Brookiyn 1. From cereliro-spinal inteningitis New York 6, Brook lyn, Somerville and Quincy I each. From malarial fover Brooklyi f, New York and l'liladelphia 2 each. From erysipelas New York "2, Chicago, Boston and fall kiver 1 oach. From small-pox Now Yorls 1.

OFFICIAL JIS'T OF CHANGLS IN THE S'TA'TIONS ANI)

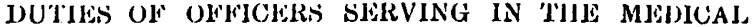
DEPARTMLN'T, U. S. ARMY, HRUM NUVEMBER 12, 184\%, Ii) NOVEMBEI 16, $18 \% 2$.

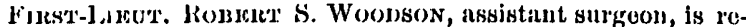
lieved from dity at Fort Melherson, Georgia, and is assigned to duty at Fort Barrancas, Floridat.

Finst-Linut. Gicolicis J. Nicwaniedicn, assistant surgeon (recently appointed) is assigned to duty at fort Sheridan, III.

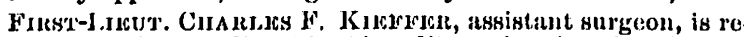
lieved from daty at frort sheridan, III., and assigned to duty at Fort Meade, South Dakotal.

Finst-LInUT. $\Lambda$. E. BRADICY, assistant surgeon, is relieved from duty as attending surgeon, Hedgrs. Bept. of the P'latte Omaha, Nobraska, and is assigned to duty at fort Sully, Soutl Dikotia.

Car'tain lonnjamin Munjay, assistant surgeon, is relieved from duty at Fort Sully, S. D., and is assigned to duty at For Nebriska, Nols.

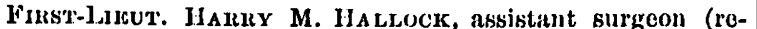
cently appointed) is assigned to duty at liort Mel'herson, Ga., for duty at that post.
Finstr-linut. HoNeY R STrLes, assistant, surgeon (recently appointed) is atssigned to duty at defferson biariacks, Mo.

Finst-LuneT. P'Aun, F. S'Traub, assistant rurgeon (recently appointed) is assigned to duty at fort Riley, Kansas.

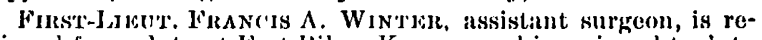
lieved from duty at. Fort Riley, Kansats, and is assigned to duty at Fort Wingate, New Mexico.

OFFICIAJ, JIST OF (HHANGES IN 'THE MEI)ICAI, CORPS OF THE U. S. NAVY TOR THE WIEKK ENJING NOVIEM BSER 19, 18!2.

Gino. T. SMITI, assistant surgeon, from C. S. S. "Hassler," and to the "Vermont."

C. H. 'T. Joundes, passed assistant surgeon, from the U. S. Receiving-slip " Vermont," and to the " IJatssler."

W. F. AleNOL1), passed assistant surgeon, to hold himself in rendiness for orders to the U.S. S. "Monterey."

H. N. 'T. Ilakris, passed assistant surgeon, to hold himsolf in readiness for orders to the U.S.S. "Biancroft."

G. If. Winstow, surgeon, to hold limself in readiness for orders to the U. S. S. "Monterey."

\section{SOCIE'TY NO'TICE.}

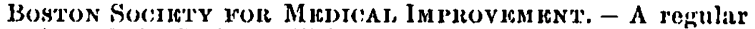
meoting of the Society will bo licld on Monday, November 28 , 18:2, at the Medical Library, 19) Boylston Place, at 8 o'clock 1'. M.

1)r. F. W. Draper: "On I'oisoning by Illuminating (ais."

J)r A. 1. Mason: "The Clinical Aspects of Gass-Poisoning in Thirty Cases."

$$
\text { (i. (i. sicnies, M.D., secretary. }
$$

\section{CLNSORS' FXAMINA'TION.}

The Censors of the Suffolk 1)istrict Medical Society, oficiating for the Society at latge, will meet for examination of candidates for admission to the Matssitchusetts Medical Society, at 1! Boylston Place, on Thursday, Deecmber 15, 18912, $2 \mathrm{r}$. M.

Candidates should make personal application to tho Secretary and present their medical diploma, or its equivalont, at least. chree dilys before the eximinations.

For further particulars, apply from 2 to 3 r. m., to

188 Marlborough Streot. JAM IES J. MiNot, M.D., S'ecretciry.

\section{IRECEN'T DEA'THS}

Gric(ronio Fiduit, M.D), of Rome, a distinguished medieal anthority and writer, died at Genon, Octobor 2tith, aged soventythree years.

ENocin Frman, M.1)., Greenwich, N. J., died November 15th, in lis one humdred and first year. Ile graduated from the University of P'ennsylvania in 1816 .

F. V. Jonnson, M.I ., of New Brighton, Staten Ishand, died November 20th, aged sixty-six yenrs. Ho griduated from the College of Pliysicians and Surgeons, N. Y., in 1852.

\section{BOOKS AND PAMPHLLES RECEIVED.}

Tho Medical News Visiting-List for 1893; 'Thirty pationts a week. Plsiladelphia: Lea Brothers \& Co.

Combined (iynecologieal Operations. By George M. Edebohls, A.M., M.D., New York. Reprint. 18:2.

The Present bemand for Better Medieal dedueation in the South. By Juther B. Grandy, M.I)., Atlanta, Ga. Reprint. 1892. Mother and Clikd. Part 1; Mother, hy delward 1'. Davis, M.1). l'art II ; Clidi, by John M. Kenting, M.D., LI.1). Phil. adelphia: J. b. Lippineott Co. 18:33.

A Pocket Medical lojetionary, giving the Pronounciation ind Definition of about 12,040 worle. liy (ieorgo M. Gould, M.1). Philadelphia: P. Blakiston, Son \& Co. 18!1E.

Practical Pathology. A Mamial for Stulents and Practitioners. lis G. Sines Woodhead, M.1)., F.R.C.P., Jirector of the baborit tories of the Conjoint Board, ote. 'Ilitird edition. Bdinburgh and London: Young J. l'entland. l'siladolphia: J. B. Lippincott Co. 18:92.

Diseases of the Lungs, Heart and Kidnoys. Hy N. S. Davis, Jr., A.M., M.1., Professor of Principles and Practice of Medicino, Clicago Medical Collogo, ete. No. 14 in the Physicians' and Students' Rendy-Roforence Sorios. Philadolphia: The $F$. A. Davis Co. 1892. 